\title{
Porous foams based hydroxyapatite prepared by direct foaming method using egg white as a pore promoter
}

\author{
H. KHALLOK ${ }^{1, *}$, S. OJALA ${ }^{2}$, M.EZZAHMOULY ${ }^{1}$, A. El OUAHLI ${ }^{1}$, EL.H. GOURRI ${ }^{1}$, M. JAMIL ${ }^{1}$ and Z. \\ HATIM $^{1}$ \\ ${ }^{1}$ Electrochemical and biomaterials team Chemistry Department, Faculty of Sciences, \\ University Chouaib Doukkali, El Jadida, Morocco. \\ ${ }^{2}$ Environmental and Chemical Engineering, Faculty of Technology University of Oulu, Finland
}

*Corresponding author: khallok.hamza76@gmail.com

\begin{abstract}
Stoichiometric Hydroxyapatite $\left(\mathrm{Ca}_{10}(\mathrm{PO})_{6}(\mathrm{OH})_{2}\right.$, HAP) foams, have been produced. The porous parts were prepared from a calcined HAP powder and egg white as a bio and nontoxic pore promoter. The colloidal slurry was prepared, poured into cylindrical molds, dried, unmolded, and sintered at $1200{ }^{\circ} \mathrm{C}$. The effects of the concentration of the solid loading, of the dispersing agent, and the foaming agent on the ceramic preparation were examined. X-Ray Diffraction (XRD) and Fourier Transform Infrared (FTIR) were used to evaluate the composition and the structure of the sintered HAP ceramics. Scanning Electron Microscopy (SEM) was used for microstructural analysis. The XRD analysis of the porous parts, prepared under optimized conditions, showed the presence of crystalized HAP (JCPDS 9-432) as a single phase. SEM images showed existence of open and interconnected micro and macro-pores in the ceramics. The use of the egg white protein as pore former provides a total porosity of 86 vol- $\%$ and a foam-structure that allows to a micro-porous wall.
\end{abstract}

Keywords: Bio ceramics, Hydroxyapatite, interconnected pores, foam, egg white.

This is a post-peer-review, pre-copyedit version of an article published in J Aust Ceram Soc.

The final authenticated version is available online at: https://doi.org/10.1007/s41779-018-0269-1 


\section{Introduction}

An increasing number of applications that require porous ceramics with 3D porosity network have appeared in the last decades, especially for environments where high temperatures, extensive wear and corrosive media are involved. Such applications include for example the filtration of molten metals, hightemperature thermal insulation, support for catalytic reactions, filtration of particulates from diesel engine exhaust gases, and filtration of hot corrosive gases in various industrial processes that required the presences of pores and especially interconnected pores[1,2]. Macroporous materials are used in various forms and compositions, including for polymer foams for packaging, lightweight aluminum structures in buildings and planes, as well as porous ceramics for the purification of water.

In tissue Engineering, the porous structure provides the basis for new tissue formation, migration and cell proliferation that cannot be favored by their equivalents in a dense form [3,4]. For bone growth, interconnected pores larger than $100 \mu \mathrm{m}$ in the diameter are required, to guarantee the supply and the circulation of the necessary nutrients [5].

Instead of powder form; using those materials as foams in waste water treatment had a more advantage, the presence of interconnected pores in the material ensures better adsorption efficiency of the matter, particularly in the meso and nano pores, while the macropores allow the flow of fluids through the ceramic body and also Increase the residence time of the matter inside the materials.

For this aim, different materials were used as precursor to produce the ceramics foams such as alumina [6], zirconia[7], Titania [8], activated carbon [9] and calcium phosphate [10].

Calcium phosphate or especially Hydroxyapatite $\left(\mathrm{Ca}_{10}(\mathrm{PO})_{6}(\mathrm{OH})_{2}\right.$ : HAP) has a similar crystalline structure of the biological apatite that can be found in hard tissue of human beings and animals $[11,12]$. Their biocompatibility with the human body and their good osteoconductivity have been widely exploited in orthopedics and dentistry [13,14].

It is generally agreed that is very difficult to create porosity inside hydroxyapatite using either the solid routes or the wet ones. The use of solid routes is very suitable for shaping using an uniaxial or isostatic press followed by a thermal treatment and blowing agents like sucrose, naphthalene and polyethylene glycol [15-19]. With this method, the size and the morphology of the macrospores is very close to the size and morphology of the blowing agent used, and their density is modulated by the amount of the used porogen. Nevertheless, using those methods has revealed their limitations particularly in the case of the porous microstructure; they lead to an uncontrolled porosity and lower interconnection between the 
macrospores [15]. Another limitation using those methods is the bad compaction ability of hydroxyapatite powder [20,21].

In the research for the better ways of porous ceramics elaboration, some other techniques have been developed such as replica [22,23], sacrificial template [24,25], and direct foaming methods [26,27]. The use of the foaming method had success in producing a porous ceramic with a porosity volume around 80 vol-\%, in which the structure of the pores was characterized by spherical interconnected cells [28,29]. However, the vast majority of this processes use solvents and templates, and among other additives, which should be removed prior the use of the resulting materials. This removal could be accomplished by a calcination process in which the materials should be consolidated near the sintering conditions, generally between $1300{ }^{\circ} \mathrm{C}$ and $1500{ }^{\circ} \mathrm{C}$ to increase their mechanical strength. The consolidation of the resulting structure from the suspended state to a rigid lattice is, in fact, the most critical step using the foaming methods, which need the use of a consolidator agent to avoid the collapsing of the resulting structure. Using the direct foaming method, the egg white, which makes the foaming easy, was chosen as a bio-pore promoter. However, in literature, some works used egg white as a pore former with which they reached a high level of porosity while the degree of interconnection was lower and the walls between the pores were too dense [30].

The work concentrates on the preparation of an interconnected porous hydroxyapatite ceramic with good mechanical texture integrity at relatively low temperatures. The egg white was used as a non-toxic pore promoter and mixed with thermally treated hydroxyapatite that has chemical and crystalline structure stability. To provide a better control of the material's microstructures the foam stability, the effects of the concentration of the solid loading and the foaming agent on the final porosity were examined. The montmorillonite-clay was used as a reinforcing agent during the consolidation process to avoid collapsing of the porous structure.

\section{Materials and methods}

\subsection{Preparation of hydroxyapatite powder}

The stoichiometric hydroxyapatite used as a precursor was synthesized by a neutralization of a lime suspension by a phosphoric acid solution. Firstly, $100 \mathrm{~g}$ of $\mathrm{CaCO}_{3}$ (Skora, analytical grade) was heated at $900^{\circ} \mathrm{C}$ during 12 hours. The obtained $\mathrm{CaO}$ powder was hydrated with double distilled water to produce $\mathrm{Ca}(\mathrm{OH})_{2}(0.6 \mathrm{~mol} / \mathrm{l})$. The orthophosphoric acid solution (1mol/l) (Merck: analytical grade) was added into $\mathrm{Ca}(\mathrm{OH})_{2}$ suspension using an automatic titration $(100 \mathrm{ml} / \mathrm{min})$ and vigorous stirring $(500 \mathrm{rpm})$. The $\mathrm{Ca} / \mathrm{P}$ molar ratio of the reagents was fixed at 1.660 (molar ratio of the stoichiometric hydroxyapatite is 1.667). The mixing was carried out at $22^{\circ} \mathrm{C}$ and at precipitation $\mathrm{pH}$ of 7.5 . The resulting precipitate was 
aged for $12 \mathrm{~h}$, decanted, and then filtered and dried at $105^{\circ} \mathrm{C}$ for 12 hours. The powder was then calcined at $900^{\circ} \mathrm{C}$ for 3 hours and milled using alumina balls $(6.5 \mathrm{~mm}$ diameter with ratio powder/balls of 1:3).

\subsection{Preparation of hydroxyapatite slurry}

The used technique, for fabrication of the porous ceramics, initially involves the preparation of aqueous slurry from a mixture of calcined hydroxyapatite powder, dispersing agent, reinforcing agent and a biologic foaming agent.

The Polyvinyl-alcohol PVA, (Merck KGaA, 64271 Darmstadt Germany) used as a dispersant, was firstly added with different weight concentration based on the hydroxyapatite powder in $20 \mathrm{ml}$ of doubledistilled water. The montmorillonite-clay (Cloisite ${ }^{\circledR} \mathrm{Na}+$ ) with a concentration of $1 \mathrm{wt}-\%$, relative to HAP powder, was added as a reinforcing agent. The mixture was heated to $60^{\circ} \mathrm{C}$ and stirred for 4 hours. The HAP powder was added to the mixture using weight fractions from 40 to $70 \mathrm{wt} \%$ relative to the slurry weight. The egg white was then added, adopting a weight fraction from 10 to $40 \mathrm{wt} \%$ relative to HAP powder. The mixture was stirred for 4 hours in order to incorporate the air bubbles into the slurry and to begin the foaming process.

\subsection{Preparation of porous parts}

The prepared mixture was poured into a cylindrical silicone mold $(3 \mathrm{~cm}$ in diameter and $0.5 \mathrm{~cm}$ in thickness) and dried firstly at $80^{\circ} \mathrm{C}$ for 1 hour and then at $105^{\circ} \mathrm{C}$ for 24 hours to eliminate the surface water and initialize the egg white consolidation. The cylindrical parts were extracted from the mold and their densities were determined by geometric measurement.

\subsection{Thermal treatment}

The molded samples were heated in the furnace in air from the room temperature to $1200{ }^{\circ} \mathrm{C}$ according to the following cycle: a heating rate of $0.5^{\circ} \mathrm{C} / \mathrm{min}$ from room temperature to $600{ }^{\circ} \mathrm{C}$ to eliminate the organic phase, a holding time of 1 hour at this temperature followed by a heating with a rate of $5{ }^{\circ} \mathrm{C} / \mathrm{min}$ up to $1200{ }^{\circ} \mathrm{C}$ and a holding time of 3 hours, and finally cooling with a rate of $2{ }^{\circ} \mathrm{C} / \mathrm{min}$ back to the room temperature.

\section{Characterization Methods}


The Infrared Spectra of the calcined powder and the sintered blocks were recorded on a Fourier Transform Spectrometer (SHIMADZU FTIR-8400S) with a resolution of $4 \mathrm{~cm}^{-1} .20$ scans were co-added and the range taken was from 400 to $4000 \mathrm{~cm}^{-1}$.

The formed crystalline phases were identified with the calcined powder using the X-ray diffraction (Diffractometer BRUKER D8 ADVANCED). Copper K $\alpha$ radiation $(\lambda=1.5406 \mathrm{~nm}$ ) produced at $50 \mathrm{kV}$ and $20 \mathrm{~mA}$ scanned the diffraction angles $2 \theta$ in the range $5-60^{\circ}$, using a step size of $0.02^{\circ}$ and a step time of $30 \mathrm{~s}$. Crystallographic identification was accomplished by comparing the experimental XRD patterns to standards compiled by the joint committee on powder diffraction standards (JCPDS), which was card \#09-0432 for HAP.

The viscosity of the slurries was determined by using a viscometer (Brookfield DVI \pm extra) while changing the temperature from 25 to $90^{\circ} \mathrm{C}$ in the share rate ranging from 0 to $700 \mathrm{~s}^{-1}$.

The microstructure of the slurry and the egg white foam were characterized by a numeric microscope Leica MZ FLII. The porosity volume of the prepared parts was calculated using the following equation:

$$
\text { Porosity vol\% }=100 *\left(1-\frac{\mathrm{d}_{\mathrm{app}}}{3.16}\right)
$$

Where $3.16 \mathrm{~g} / \mathrm{cm}^{3}$ is the theoretical density of hydroxyapatite.

The apparent density $\left(\mathrm{d}_{\mathrm{app}}\right)$ was measured based on the weight and the dimensions of the solid blocks before and after calcination.

The Microstructural observations of the overall porous structures were performed on the surface and inside the solid blocks by using a Scanning Electron Microscope (SEM) (Carl Zeiss EVO50 XPV +Röntec X-flash detector type 1106). The pore sizes were determined by SEM images using ImageJ Software.

\section{Results \& discussion}

\subsection{Powder characterization}

The FTIR results of HAP powder and sintered parts are given in Fig.1. The observed IR absorption bands of HAP calcined at $900{ }^{\circ} \mathrm{C}$ around 475, 575, 600,960,1040, and $1090 \mathrm{~cm}^{-1}$, are characteristic of the $\mathrm{PO}_{4}{ }^{3-}$ group present in the theoretical stoichiometric hydroxyapatite, while other bands at 3570 and 630 $\mathrm{cm}^{-1}$ referred to the vibration of the hydroxyl groups $(\mathrm{OH})$. The detected bands at around $3500 \mathrm{~cm}^{-1}$ were attributed to the water adsorbed on the surface of the hydroxyapatite powder. The Infrared spectrum of the porous parts calcined at $1200^{\circ} \mathrm{C}$ shows a great thermal stability and no change in the composition was observed when the results were compared to the precursor powder. 


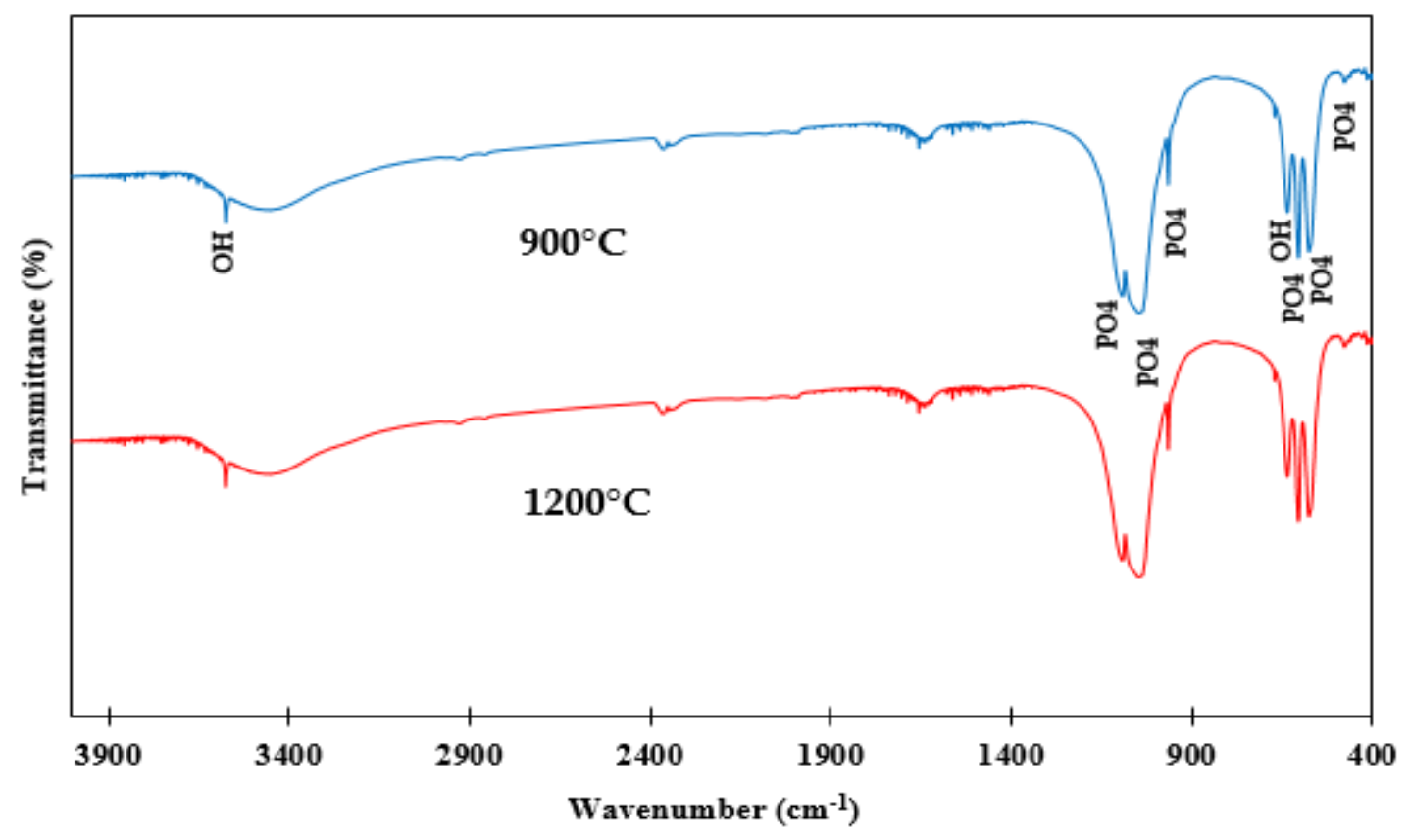

Fig.1: FTIR spectrum of hydroxyapatite precursor powder calcined at $900^{\circ} \mathrm{C}$ and final solid blocks sintered at $1200^{\circ} \mathrm{C}$

The XRD pattern of precursor HAP powder and porous blocks calcined at $1200^{\circ} \mathrm{C}$ is reported in Fig.2. The result shows a pure and well-characterized peak of stoichiometric HAP, which is indexed referred to (JCPDS 9-432).

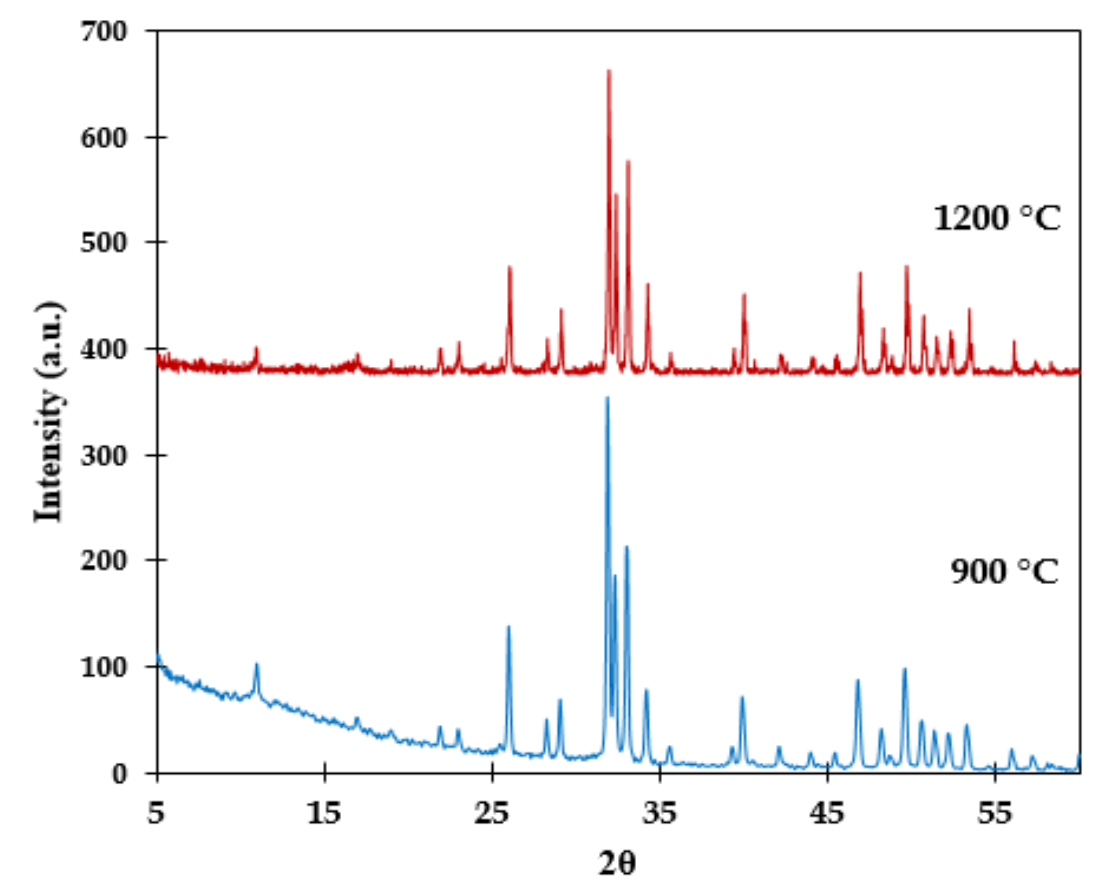

Fig.2: XRD patterns of hydroxyapatite precursor powder calcined at $900^{\circ} \mathrm{C}$

\subsection{Characterization of the slurry}


Looking for a compromise between slip viscosity and foam volume proprieties, the preparation of the slurries was done by varying the concentration of the calcined HAP powder from 40 to $70 \mathrm{wt} \%$. An example of a microstructure of the solid blocks obtained using $70 \mathrm{wt}-\%$ of solid loading did not show the homogeneous pore distribution as visualized in Fig.3-A.

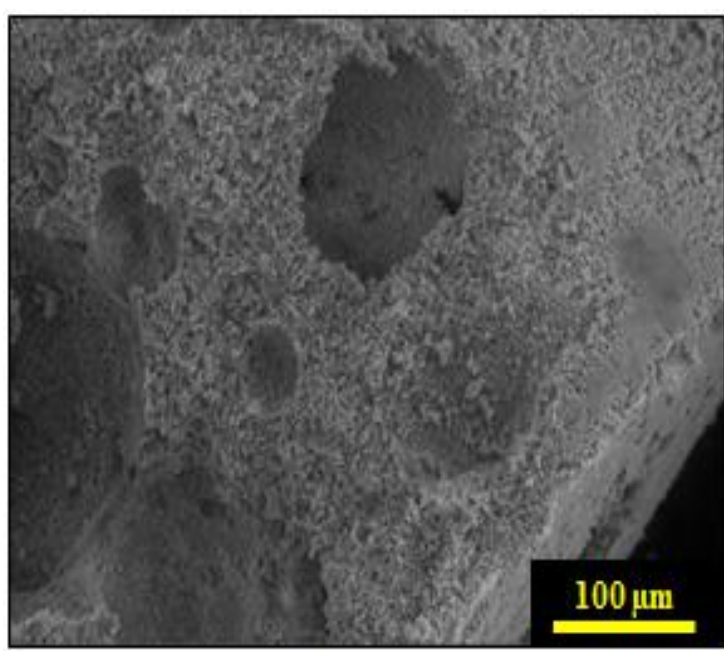

A

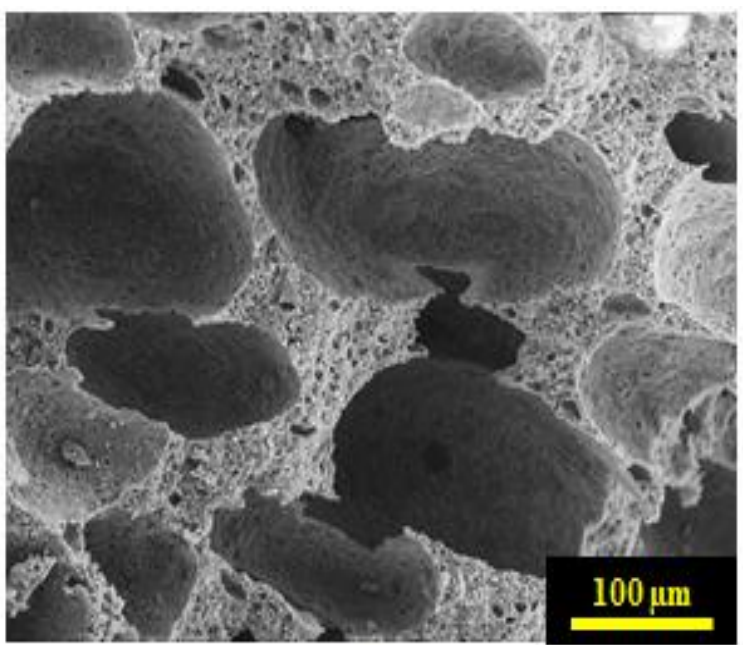

B

Fig. 3 : SEM image of the bulk of the obtained foams with 1 wt $\%$ of Montmorllionite using A: 70 $\mathrm{wt} \%$ and B: $60 \mathrm{wt} \%$ of solid loading

Using a high solid loading made casting difficult, because a higher viscosity makes it difficult to disperse air bubbles homogeneously during the stirring of the egg white. This causes the collapse of the air bubbles or segregation of the bubbles in some areas in the slurry that have a weak share rate, which creates porosity only in a few zones in the solid blocks as it is seen in the SEM image (Fig.3-A). This nonhomogeneity results in a dense structure instead of highly porous network. This result is in accordance with the literature - using a higher solid loading has an effect on maximizing the molded density and minimizing the shrinkage during the firing process, which leads to a lower porosity of the finals solid blocks [30]. However, using a solid loading of $60 \mathrm{wt}-\%$ allowed to an easy casting, characterized by fully porous structure with homogeneously distributed nearly spherical pores without any defects in the ceramic structure as illustrated in Figure 3-B. Below $60 \mathrm{wt}-\%$ of solid loading, the slurry exhibited too low viscosity, which formed unstable foams. In this case the slurry suffers from a rapid collapse of bubbles, and weak structure of resulting ceramics.

To provide a better control of the dispersion of the bubbles and the stability of the slurry, the concentration of the PVA was varied between 0 and $120 \mathrm{mg} / \mathrm{g}$ relative to the HAP powder and the viscosity was measured as an indicator for a good dispersion. Fig. 4 illustrates the viscosity of the slurry prepared with 60 wt- $\%$ of solid loading versus the dispersant concentration. The result shows that for a 
concentration of $10 \mathrm{mg} / \mathrm{g}$, the slurries present a high value of viscosity (36 Pas.s) which was not optimal for casting. However, an amount of $50 \mathrm{mg} / \mathrm{g}$ of dispersant, allowed a minimum viscosity of 12 Pas.s while above this level, a significant increase in viscosity took place. From this result, the optimum of slurry viscosity was obtained with $50 \mathrm{mg} / \mathrm{g}$ of PVA using $60 \mathrm{wt}-\%$ as solid loading of hydroxyapatite powder.

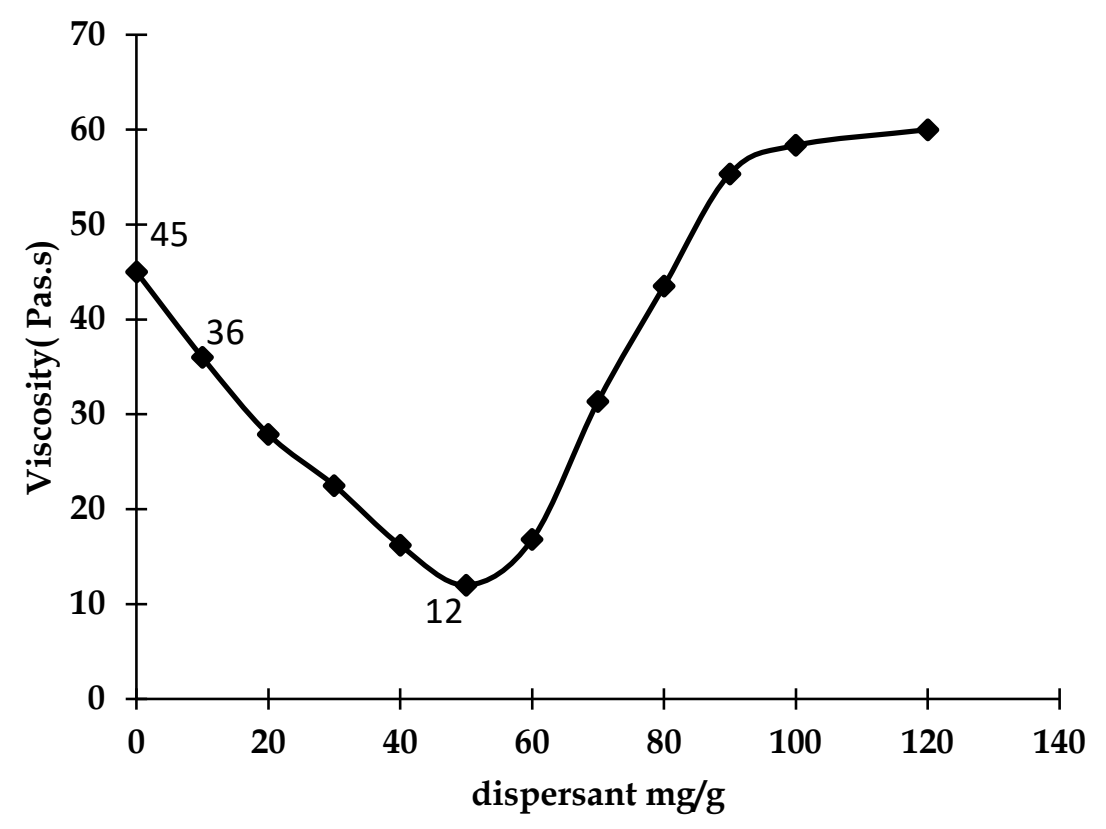

Fig. 4: Viscosity curve of HAP slurry versus the PVA concentration

To generate the porosity inside the ceramic matrix, the egg white was added, and its concentration was varied from 0 to $40 \mathrm{wt}-\%$ while the viscosity was measured as an indicator of the dispersion state of the slurries. From Fig.5 it could be seen that when increasing the amount of the egg white, the viscosity of slurry decreases significantly from 12 to 1 Pas.s. An increase of the share rate shows a decrease in the viscosity even if the amount of white egg was high. This is because the egg white contains the albumin protein that plays a role of an organic deflocculant, which once is strongly stirred, forms a very thin films that turn around the hydroxyapatite particles and separate them. 


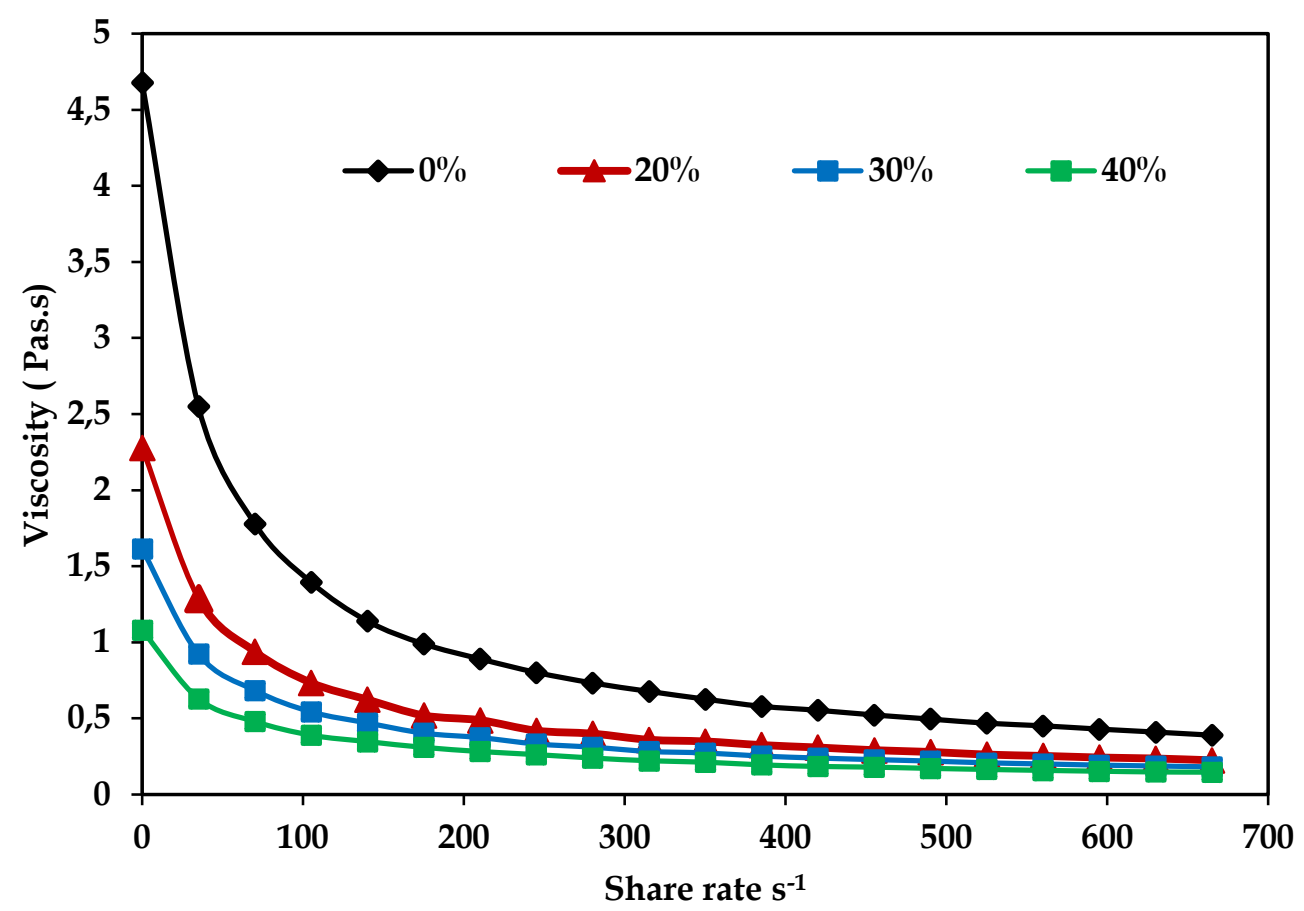

Fig.5: Viscosity variation of HAP-egg white slurry versus share rate

Using $40 \mathrm{wt} \%$ of egg white contributes not only to the incorporation of the air bubbles in the slurry but also to an increase in the fluidity of the slurries which make the molding easier. However even with a viscosity of 1 Pas.s using $40 \mathrm{wt} \%$ of eggs white, the obtained foam was stable and do not colapse during time as seen in Fig.6.

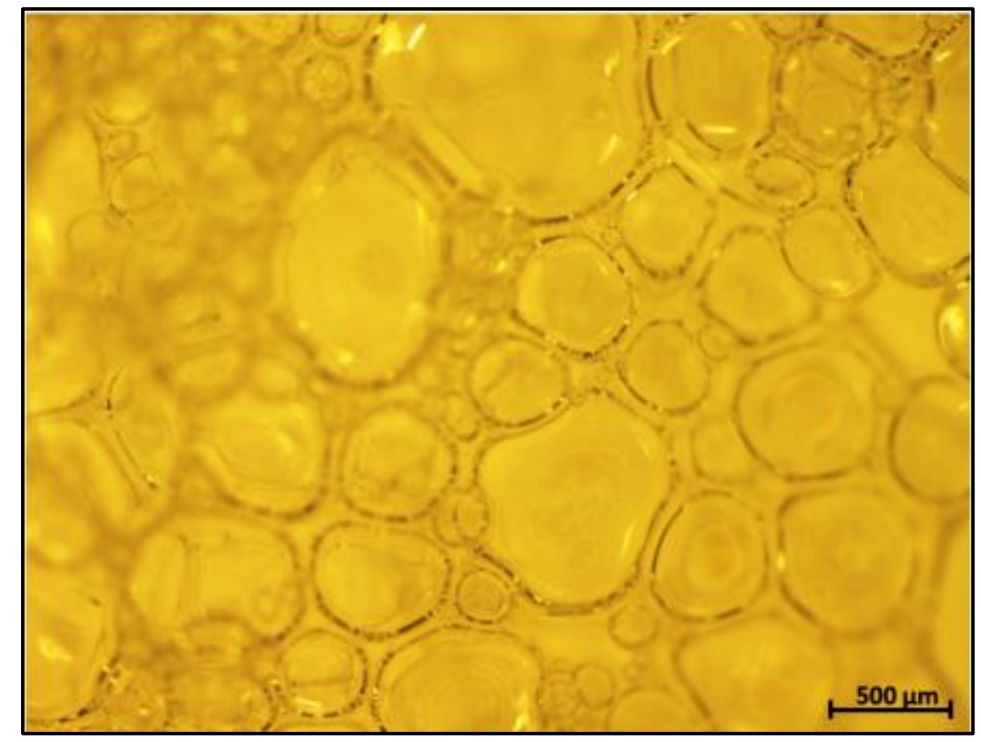

Fig.6 : Numerical image of the Microstructure of hydroxyapatite slurry foam

To determine the gelation, point of the eggs white, the gelation behavior of the suspension was then examined with an increase in temperature from 25 to $90^{\circ} \mathrm{C}$ (Fig.7). 
The result shows that the gelation behavior of the slurries increases with the temperature, however, the gelling point does not change significantly with increasing the protein amount from 0 to $40 \mathrm{wt}-\%$. This result is in accordance with the works of Ferrera [29].

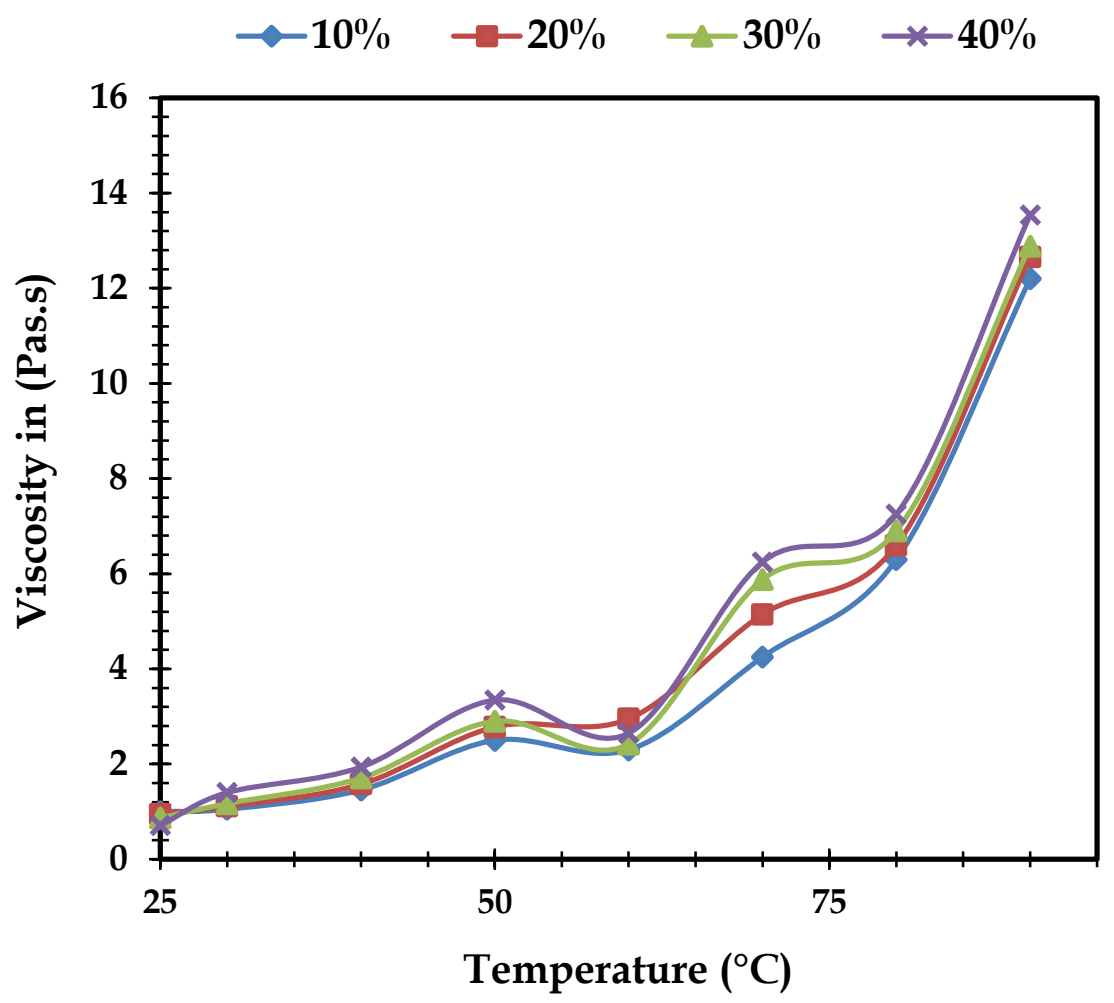

Fig.7: Variation of viscosity of HAP-eggs white slurry versus temperature

\subsection{Characterization of porous ceramic solids}

The porous ceramics were prepared under the following optimized conditions: Colloidal slurry was made using $60 \mathrm{wt}-\%$ of calcined HAP powder, $40 \mathrm{wt}-\%$ of egg white, and $1 \mathrm{wt}-\%$ of montmorillonite-clay relative to HAP powder. The heat treatment included a holding time at $600{ }^{\circ} \mathrm{C}$ with $2{ }^{\circ} \mathrm{C} / \mathrm{min}$ and another one at $1200{ }^{\circ} \mathrm{C}$ with $5{ }^{\circ} \mathrm{C} / \mathrm{min}$.

The SEM images illustrate that this preparation method provides highly porous walls between the macrospores (Fig.8.D) compared to other works reported using the same pore promoter [29]. As it showed in SEM images, the pores, had a spherical shape and their sizes ranged from micro to macrospores, which were interconnected to each other as seen in Fig. 8-C. 


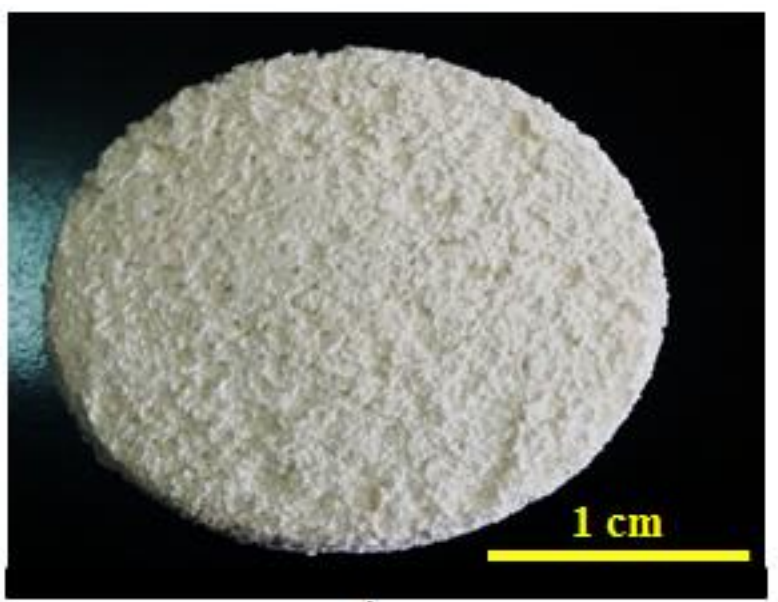

A

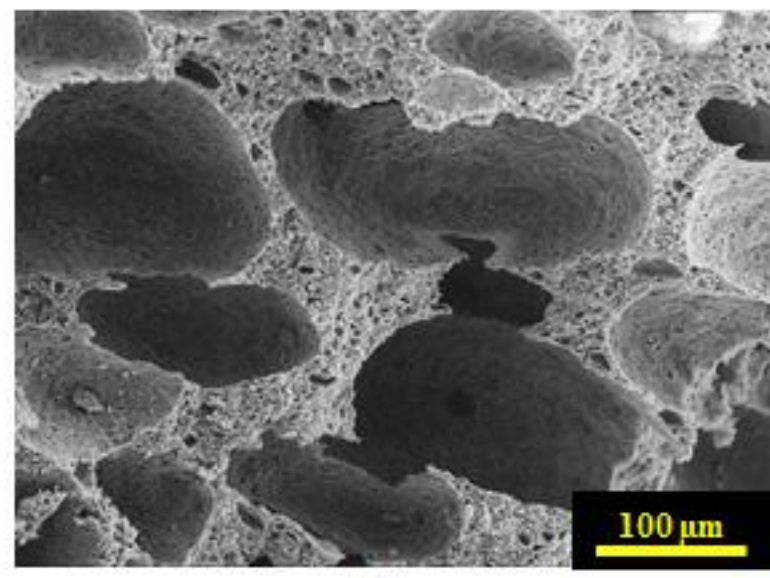

D

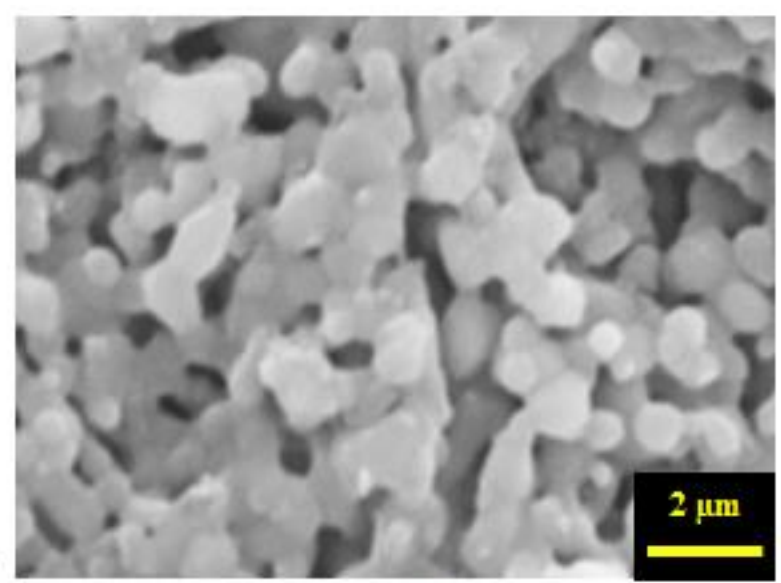

B

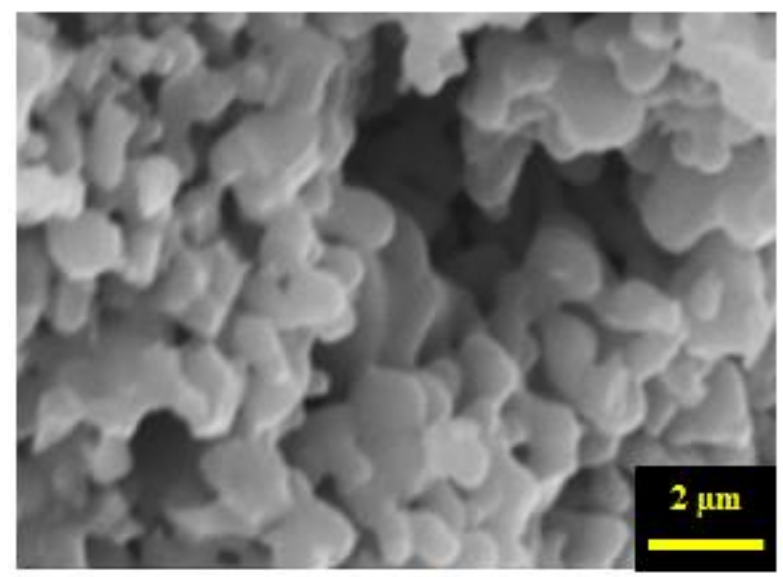

$\mathbf{C}$

Fig.8: Photography of sintered parts A. SEM Images: Surface details B, inside overview C and walls details D.

The use of the clay component in the colloidal slurry provides an appropriate mechanical texture for the fired (calcined) solid blocks and reduces also the consolidation temperature. Hesaki and Zamani [31] have demonstrated that the use of clay has a great effect on the mechanical strength of the porous parts after and during the firing process. The Montmorillonite-clay is a material that has a special property to form a thixotropic slurry with water[31]. Thanks to this superior plasticity the hydroxyapatite parts made with montmorillonite demonstrated an appropriate mechanical strength without eroded particles compared to those prepared without montmorillonite as shown in Fig.9. The handling property of clay contributes to the stabilization of the structure during the firing (calcination) step when the egg white's proteins begin to decompose at a temperature between $200^{\circ} \mathrm{C}$ and $600{ }^{\circ} \mathrm{C}$. 


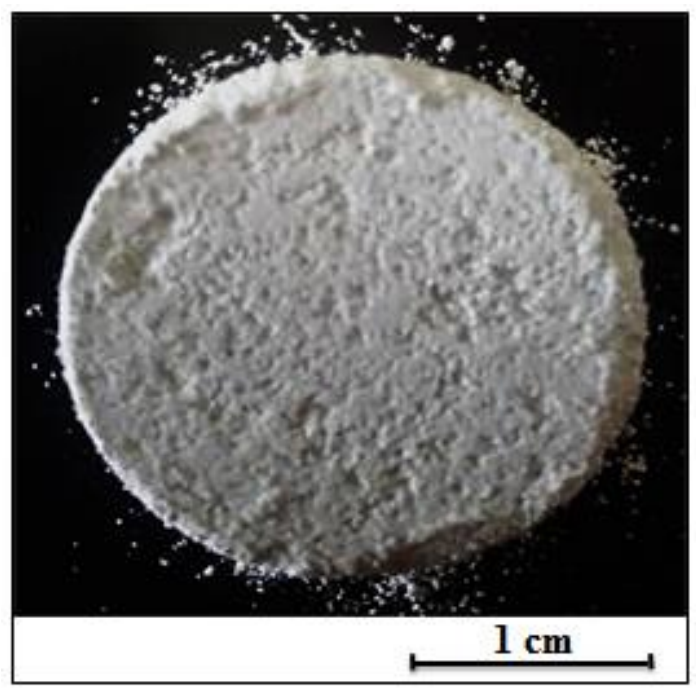

A

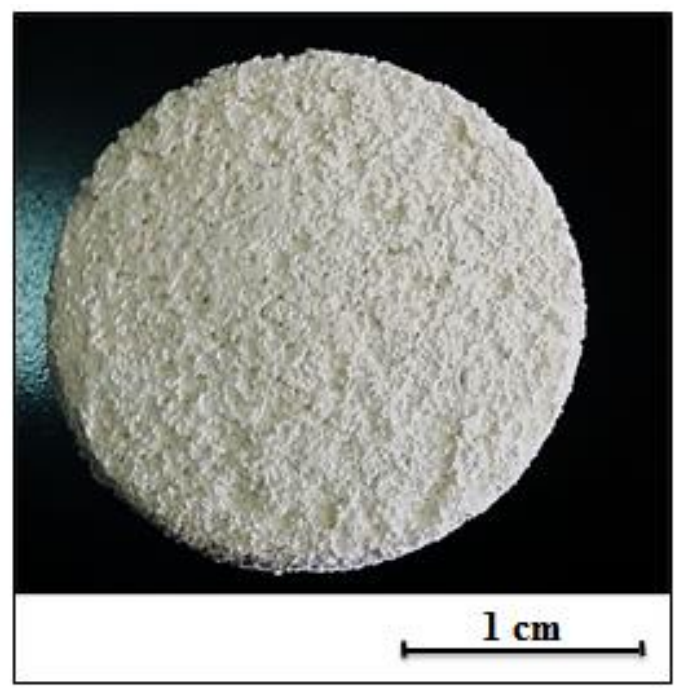

B

Fig.9: Photography of Porous hydroxyapatite ceramics prepared: Without montmorillonite-clay A, and with $1 \mathrm{wt} \%$ of montmorillonite-clay B

The IR spectra (Fig.1) and XRD diffractograms (Fig.2) show that the calcined parts at $1200{ }^{\circ} \mathrm{C}$ kept their chemical composition as a single phase of hydroxyapatite and showed no decomposition even with adding $1 \mathrm{wt} \%$ of montmorillonite as a reinforcing agent.

The densities and the pore volumes of the solid blocks were determined by measuring their apparent weight and volume before and after firing (calcination). The result shown in Table 1 reveal a decrease in the density of the solids after the heating due to the evaporation of the organic compounds giving a large volume of porosity of $86 \%$ vol.

Table 1: Density and porosity measurement before and after firing of ceramic

\begin{tabular}{|c|c|c|}
\hline Property & Density $\left(\mathbf{g} / \mathbf{c m}^{\mathbf{3}}\right)$ & Porosity $(\mathbf{\%}$ Vol $)$ \\
\hline Green ceramic & 0.70 & 22 \\
\hline Fired ceramic & 0.44 & 86 \\
\hline
\end{tabular}

After processing the SEM image with Image $\mathbf{J}$ software, the obtained pore size was from $3 \mu \mathrm{m}$ to 600 $\mu \mathrm{m}$ (Fig. 10) which is centered in $230 \mu \mathrm{m}$. The ratio of micro to macropores in the final ceramic foam may be adjusted to a certain extent by controlling the suspension viscosity [32]. 

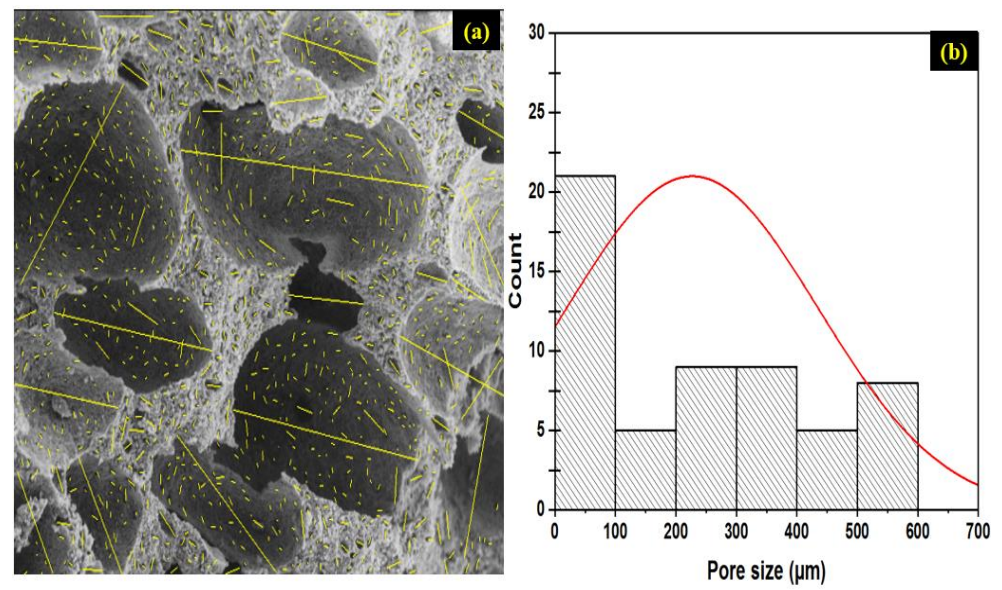

Fig.10: a) Analysis by Image-J software and b) Pore size distribution

The microstructure of ceramics obtained with egg white could be explained by the following mechanism: The egg white is heterogeneous in nature, composed by a mixture of water (90\%) and protein (10\%) connected by hydrogen bonds. When the stirring of the egg white becomes higher, the weakest hydrogen bonds are broken [33]. Then, the protein unfolds and becomes a long chain of amino acids. Therefore, the air is entrapped by the protein and when they meet other protein and water molecules, they could bind bridges with them making a network of stable foam as it is described in Fig.11-b.

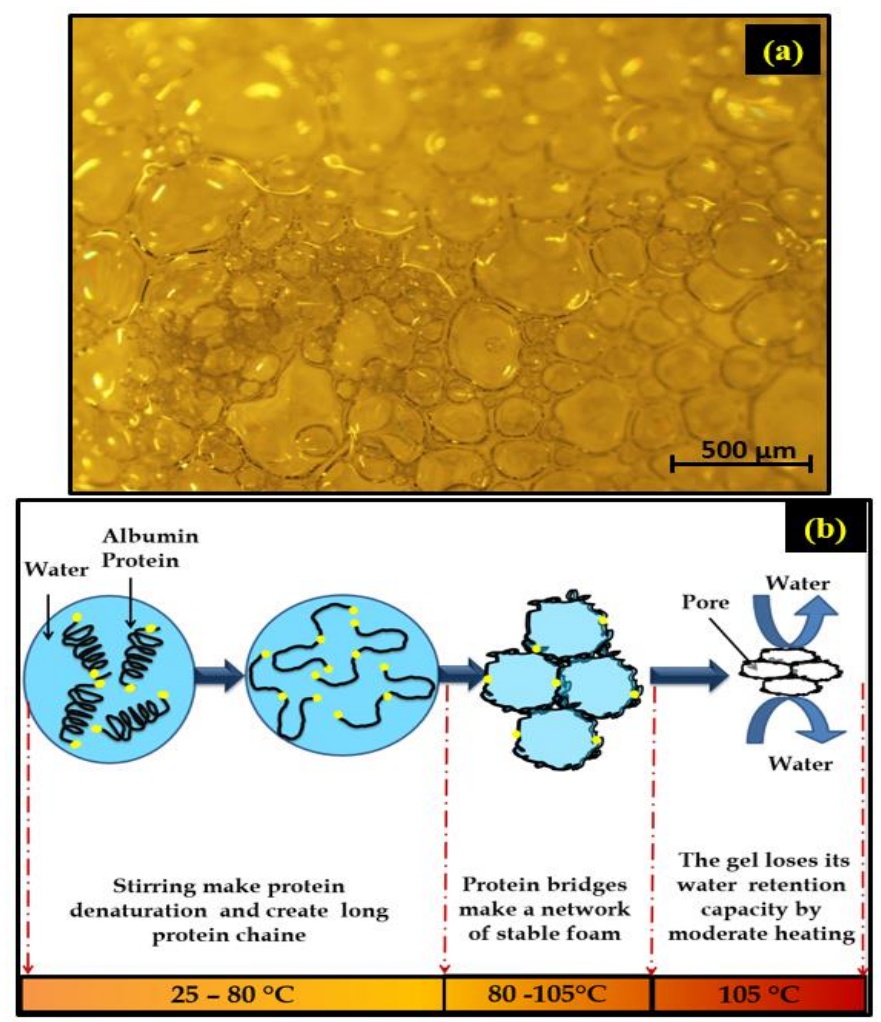

Fig.11: (a) Optical microscope image of the microstructure of the foam formed by agitation of the egg white; (b): Schematic description of denaturation and gelling process of the white egg in water versus temperature 
The porous structure in the final ceramic, comes from the incorporation of the air bubbles generated and entrapped during the mixing when stirred [34] : the introduction of air bubbles in water does not foam water on itself, but it has an effect on the egg white protein during the stirring. The protein unfolds and attaches around air bubbles retaining the water and preventing air to escape[32,34]. With high stirring speed, stable pseudo homogenous hydroxyapatite slurry was obtained as shown in Fig.11-a.

The prepared mixture was poured into a cylindrical silicone mold. Then, the mixture was dried at $80^{\circ} \mathrm{C}$ to eliminate the surface water and to initialize the egg white consolidation. This favors the coagulation of egg white (Fig.7). Thanks to the organic chains, and the hydrophilic character of the albumin, the HAP particles are bonded to each other, while the air bubbles are trapped between them. Increasing the temperature to $600^{\circ} \mathrm{C}$ the egg white protein is eliminated, which leads to the formation of the pores clearly visible by the naked eye as well as by the scanning microscope as shown in Fig.8.

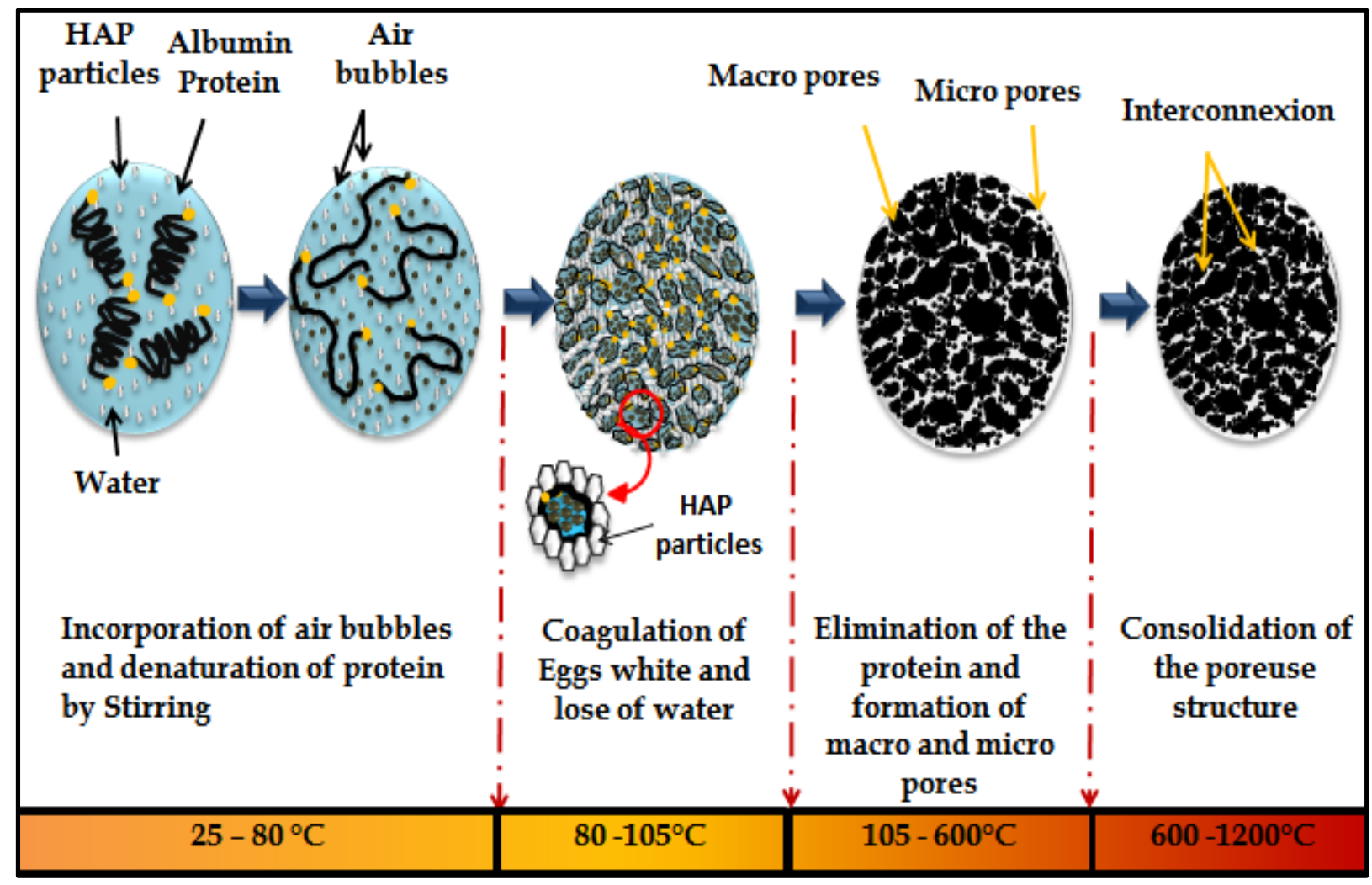

Fig.12: Schematic description of hydroxyapatite foams preparation

The ability of the egg white to bond the hydroxyapatite particles together allows the creation of walls between them. When the solid blocks are calcined at $600{ }^{\circ} \mathrm{C}$, these walls lose the organic matter that they contain, leaving microspores that promote the connection of the macropores as described in Fig. 12. The moderate calcination at $1200{ }^{\circ} \mathrm{C}$ favors the consolidation of the porous parts, since the elimination of the organic phase at $600^{\circ} \mathrm{C}$ makes the mechanical texture of the blocks weaker. As it was confirmed by the SEM images (Fig.8), the microstructure of prepared blocks was similar to the trabecular bone in terms 
of composition, porosity and interconnectivity. The surface of the porous bodies was rough, favoring cellular adhesion and the growth of the bone $[23,35,36]$.

\section{Conclusion}

In this study, a stoichiometric hydroxyapatite $\left(\mathrm{Ca}_{10}(\mathrm{PO})_{6}(\mathrm{OH})_{2}\right)$ was successfully prepared with the neutralization method, the composition analysis of those material showed the absence of any other component than the hydroxyapatite.

The foaming method had successfully allowed to a fully porous structure using egg white as non-toxic pore promoter. The control of the foam stability by optimizing the concentrations of the solid loading, the dispersant agent and of the foaming agent lead to porous ceramics with a total porosity of 86 vol- $\%$, having pore sizes from $3 \mu \mathrm{m}$ to $600 \mu \mathrm{m}$ with high macro-porous interconnectivity and micro-porous walls. The addition of the montmorillonite clay in the colloidal suspension allowed maintaining the microstructure during the consolidation cycle and to a good mechanical stability of the sintered parts.

\section{References}

[1] M. Scheffler, P. Colombo, Cellular Ceramics: Structure, Manufacturing, Properties and Applications, 2006. doi:10.1002/3527606696.

[2] L.J. Gauckler, M.M. Waeber, C. Conti, M. Jacob-Duliere, Ceramic Foam For Molten metal Filtration, JOM. 37 (1985) 47-50. doi:10.1007/BF03258640.

[3] E. Cunningham, N. Dunne, G. Walker, C. Maggs, R. Wilcox, F. Buchanan, Hydroxyapatite bone substitutes developed via replication of natural marine sponges, J. Mater. Sci. Mater. Med. 21 (2009) 2255-2261. doi:10.1007/s10856-009-3961-4.

[4] T. Dutta Roy, J.L. Simon, J.L. Ricci, E.D. Rekow, V.P. Thompson, J.R. Parsons, Performance of hydroxyapatite bone repair scaffolds created via three-dimensional fabrication techniques., J. Biomed. Mater. Res. A. 67 (2003) 1228-1237. doi:10.1002/jbm.a.20034.

[5] B. Mueller, L. Treccani, K. Rezwan, Antibacterial active open-porous hydroxyapatite/lysozyme scaffolds suitable as bone graft and depot for localised drug delivery, J. Biomater. Appl. 31 (2017) 0885328216688074. doi:10.1177/0885328216688074.

[6] M.D.D.M. Innocentini, V.Di. Rasteira, M. Potoczek, A. Chmielarz, E. Kocyło, Physical, fluid dynamic and mechanical properties of alumina gel-cast foams manufactured using agarose or ovalbumin as gelling agents, J. Mater. Res. 32 (2017) 2810-2818. doi:10.1557/jmr.2017.263.

[7] P. Biswas, K. Varaprasad, P. Ramavath, M.B. Suresh, A.K. Khanra, R. Johnson, Development of Cordierite Based Reticulated Foams with Improved Mechanical Properties for Porous Burner 
Applications, Trans. Indian Ceram. Soc. 76 (2017) 56-61.

doi:10.1080/0371750X.2016.1232178.

[8] C. Dionigi, L.F. Liotta, L. Ortolani, G. Pantaleo, T. Ivanovska, G. Ruani, New active mesoporous titania foam as size limiter for metal nanoparticles, J. Alloys Compd. 735 (2018) 16111619. doi:10.1016/j.jallcom.2017.11.305.

[9] A. Arami-Niya, T.E. Rufford, Z. Zhu, Activated carbon monoliths with hierarchical pore structure from tar pitch and coal powder for the adsorption of $\mathrm{CO} 2, \mathrm{CH} 4$ and N2, Carbon N. Y. 103 (2016) 115-124. doi:10.1016/j.carbon.2016.02.098.

[10] M. Meskinfam, S. Bertoldi, N. Albanese, A. Cerri, M.C. Tanzi, R. Imani, N. Baheiraei, M. Farokhi, S. Farè, Polyurethane foam/nano hydroxyapatite composite as a suitable scaffold for bone tissue regeneration, Mater. Sci. Eng. C. 82 (2018) 130-140.

doi:https://doi.org/10.1016/j.msec.2017.08.064.

[11] K. de Groot, Bioceramics consisting of calcium phosphate salts, Biomaterials. 1 (1980) 47-50. doi:10.1016/0142-9612(80)90059-9.

[12] L.L. Hench, Third-Generation Biomedical Materials, Science (80-. ). 295 (2002) 1014-1017. doi:10.1126/science.1067404.

[13] N. Kantharia, S. Naik, S. Apte, M. Kheur, S. Kheur, B. Kale, Nano-hydroxyapatite and its contemporary applications, Bone. 34 (2014) 1-71. http://www.iadrsd.org/wpcontent/journal/JDRSD_15_13R6.pdf.

[14] M. Oliveira, H.S. Mansur, Synthetic tooth enamel: SEM characterization of a fluoride hydroxyapatite coating for dentistry applications, Mater. Res. 10 (2007) 115-118. http://www.scielo.br/scielo.php?script=sci_arttext\&pid=S1516-14392007000200004\&nrm=iso.

[15] E. Chevalier, D. Chulia, C. Pouget, M. Viana, Fabrication of porous substrates: A review of processes using pore forming agents in the biomaterial field, J. Pharm. Sci. 97 (2008) 11351154. doi:10.1002/jps.21059.

[16] M. Castilho, C. Moseke, A. Ewald, U. Gbureck, J. Groll, I. Pires, J. Teßmar, E. Vorndran, Direct 3D powder printing of biphasic calcium phosphate scaffolds for substitution of complex bone defects, Biofabrication. 6 (2014) 015006. doi:10.1088/1758-5082/6/1/015006.

[17] F. Tancret, J.M. Bouler, J. Chamousset, L.M. Minois, Modelling the mechanical properties of microporous and macroporous biphasic calcium phosphate bioceramics, J. Eur. Ceram. Soc. 26 (2006) 3647-3656. doi:10.1016/j.jeurceramsoc.2005.12.015.

[18] C. Wang, T. Kasuga, M. Nogami, Macroporous calcium phosphate glass-ceramic prepared by two-step pressing technique and using sucrose as a pore former, J. Mater. Sci. Mater. Med. 16 
(2005) 739-744. doi:10.1007/s10856-005-2611-8.

[19] D.S.H. Lee, Y. Pai, S. Chang, D.H. Kim, Microstructure, physical properties, and bone regeneration effect of the nano-sized $\beta$-tricalcium phosphate granules, Mater. Sci. Eng. C. 58 (2016) 971-976. doi:https://doi.org/10.1016/j.msec.2015.09.047.

[20] Z. Hatim, A. Michrafy, M. Elassfouri, F. Abida, Stoichiometry and particle morphology effects on the aptitude to compaction of apatitic structure powders, Powder Technol. 190 (2009) 210214. doi:10.1016/j.powtec.2008.04.040.

[21] C. Pontier, M. Viana, E. Champion, D. Bernache-Assollant, D. Chulia, About the use of stoichiometric hydroxyapatite in compression - Incidence of manufacturing process on compressibility, Eur. J. Pharm. Biopharm. 51 (2001) 249-257. doi:10.1016/S09396411(01)00137-0.

[22] F. Gervaso, S.K. Padmanabhan, F. Scalera, A. Sannino, A. Licciulli, Mechanical stability of highly porous hydroxyapatite scaffolds during different stages of in vitro studies, Mater. Lett. 185 (2016) 239-242. doi:https://doi.org/10.1016/j.matlet.2016.08.139.

[23] H.R. Ramay, M. Zhang, Preparation of porous hydroxyapatite scaffolds by combination of the gel-casting and polymer sponge methods, Biomaterials. 24 (2003) 3293-3302. doi:10.1016/S0142-9612(03)00171-6.

[24] R. Poorvisha, S.P. Suriyaraj, P. Thavamani, R. Naidu, M. Megharaj, A. Bhattacharyya, R. Selvakumar, Synthesis and characterisation of 3-dimensional hydroxyapatite nanostructures using a thermoplastic polyurethane nanofiber sacrificial template, RSC Adv. 5 (2015) 9777397780. doi:10.1039/C5RA18593A.

[25] M. Farrokhi-Rad, S.K. Loghmani, T. Shahrabi, S. Khanmohammadi, Electrophoretic deposition of hydroxyapatite nanostructured coatings with controlled porosity, J. Eur. Ceram. Soc. 34 (2014) 97-106. doi:10.1016/j.jeurceramsoc.2013.07.022.

[26] S. Woottichaiwat, S. Puajindanetr, S.M. Best, Fabrication of porous hydroxyapatite through combination of sacrificial template and direct foaming techniques, Eng. J. 15 (2011) 1-15. doi:10.4186/ej.2011.15.2.1.

[27] M. Potoczek, Hydroxyapatite foams produced by gelcasting using agarose, Mater. Lett. 62 (2008) 1055-1057. doi:10.1016/j.matlet.2007.07.043.

[28] A. Naqshbandi, I. Sopyan, Gunawan, Development of Porous Calcium Phosphate Bioceramics for Bone Implant Applications: A Review, Recent Patents Mater. Sci. 6 (2013) 238-252. doi:10.2174/18744648113069990012.

[29] A.F. Lemos, J.M.F. Ferreira, Combining Foaming and Starch Consolidation Methods to Develop 
Macroporous Hydroxyapatite Implants, in: Key Eng. Mater., 254-256 (2004): pp. 1041-1044. doi:10.4028/www.scientific.net/KEM.254-256.1041.

[30] A. Macchetta, I.G. Turner, C.R. Bowen, Fabrication of HA/TCP scaffolds with a graded and porous structure using a camphene-based freeze-casting method, Acta Biomater. 5 (2009) 13191327. doi:https://doi.org/10.1016/j.actbio.2008.11.009.

[31] S. Hesaraki, A. Zamanian, M. Hafezi, Montmorillonite-Added Calcium Phosphate Bioceramic Foams, Key Eng. Mater. 361-363 (2008)111-114. doi:10.4028/www.scientific.net/KEM.361363.111 .

[32] A.C. Rust, M. Manga, Effects of bubble deformation on the viscosity of dilute suspensions, J. Nonnewton. Fluid Mech. 104 (2002) 53-63. doi:10.1016/S0377-0257(02)00013-7.

[33] Y.-F. Liu, I. Oey, P. Bremer, A. Carne, P. Silcock, Effects of pH, temperature and pulsed electric fields on the turbidity and protein aggregation of ovomucin-depleted egg white, Food Res. Int. 91 (2017) 161-170. doi:10.1016/j.foodres.2016.12.005.

[34] A.R. Studart, U.T. Gonzenbach, E. Tervoort, L.J. Gauckler, Processing routes to macroporous ceramics: A review, in: J. Am. Ceram. Soc.,89 (2006) 1771-1789. doi:10.1111/j.15512916.2006.01044.x.

[35] J. Liu, X. Miao, Porous alumina ceramics prepared by slurry infiltration of expanded polystyrene beads, J. Mater. Sci. 40 (2005) 6145-6150. doi:10.1007/s10853-005-3165-3.

[36] E.B. Montufar, T. Traykova, E. Schacht, L. Ambrosio, M. Santin, J.A. Planell, M.-P. Ginebra, Self-hardening calcium deficient hydroxyapatite/gelatine foams for bone regeneration, J. Mater. Sci. Mater. Med. 21 (2010) 863-869. doi:10.1007/s10856-009-3918-7. 